\title{
The Evaluation of Dietary Addition of Palm and Coconut Oils in Steaming Tomato (Lycopersicon esculentum) Waste Powder on Digestibility of Crude Fiber and Retention of Lycopene and Nitrogen in Broiler Chickens
}

\author{
Ulvi Fitri Handayani ${ }^{1}$, Wizna ${ }^{2}$, Irfan Suliansyah ${ }^{3}$, Yose Rizal $^{2}$ and Maria Endo Mahata ${ }^{2^{*}}$ \\ ${ }^{I}$ PhD Student at Graduate Program of Faculty of Agriculture Science in Universitas Andalas, Kampus Limau Manis, Padang, 25163, Indonesia \\ ${ }^{2}$ Lecturer at Under Graduate of Faculty of Animal Science, Universitas Andalas, and Graduate Program at Universitas Andalas, Kampus Limau \\ Manis, Padang, 25163, Indonesia \\ ${ }^{3}$ Lecturer at Under Graduate of Faculty of Agriculture Science, Universitas Andalas, and Graduate Program at Universitas Andalas, Kampus \\ Limau Manis, Padang, 25163, Indonesia \\ ${ }^{*}$ Correspondent author’s Email: mariamahata@ gmail.com; ORCID: 0000-0002-4692-9806
}

Received: 18 Oct 2019

Accepted: 26 Nov 2019

\begin{abstract}
Lycopene is a powerful antioxidant present in tomatoes and other vegetables and fruits. Present research was carried out to evaluate lycopene and nitrogen retention and crude fiber (CF) digestibility of steaming tomatoes waste powder which was combined with oil. Tomatoes waste in this experiment were local fresh tomato rejected from tomato field around West Sumatera province, Indonesia. The experimental factors were included the type of oil (palm and coconut oils) and dosage of oils $(0.25,0.5,0.75,1$, and $1.25 \%)$, and each treatment was replicated three times. The results indicated there was an interaction between the type of oil and dosage of oil on lycopene retention, and CF digestibility, while the type of oil and dosage of oil affected lycopene retention significantly. The dosage of oil also influenced lycopene retention, nitrogen retention, CF digestibility significantly. The addition of coconut oil in steaming tomato waste powder increased lycopene and nitrogen retention, and CF digestibility higher than the addition of palm oil to steaming tomato waste powder in broiler chickens. The lycopene and nitrogen retention, and CF digestibility of steaming tomato waste powder added $0.5 \%$ coconut oil was the best level for lycopene and nitrogen retention, and CF digestibility in broiler chickens.
\end{abstract}

Key words: Coconut oil, Crude fiber digestibility, Lycopene retention, Nitrogen retention, Palm oil, Tomatoes waste

\section{INTRODUCTION}

Recently, researches on poultry nutrition were conducted to find cheaper and high quality feeds. One of the famous active compound in tomato is lycopene. This compound is beneficial for human and livestock health (Bramley, 2000). Lycopene was known as a substance that has high antioxidant ability (Dewanto et al., 2002; Toor and Savage, 2005; Gupta et al., 2011; Surai, 2016). In addition, lycopene also has an important role to reduce cholesterol level in the body (Palozza et al., 2012). Lycopene can inhibit HMG-CoA reductase to synthesize mevalonate from HMG-CoA, resulting in reducing of cholesterol level in the body (Palozza et al., 2012).

Previous research showed lycopene and tomato wastes have been widely used as feed mixtures in poultry. This research shown, that semen production and viability were affected by lycopene supplementation in broiler breeder (Mangiagalli and Taylor, 2010). It could reduce cholesterol content in meat (Mahata et al. 2016 a), and in serum of broiler chickens (Mahata et al., 2016a) and laying hen (Mahata et al., 2016b), and it also improved poultry immunity status (Olson et al., 2005; Mangiagalli and Taylor, 2010; Sun et al., 2015). Generally, lycopene structure in fresh tomato is in trans form, and it is very stable so that it is difficult to absorb by animals and humans digestive tract (Unlu et al., 2007; Knockaert et al., 2012; Meroni and Raikos 2018). Handayani et al. (2018) reported that to increase the availability of cis-lycopene and its absorption in poultry digestive tract, fresh tomato should be treated by steaming for 12 minutes at temperature $98{ }^{0} \mathrm{C}$. This treating will change the structure of lycopene in fresh tomato from trans structure to cis structure. 
One of the characteristics of lycopene is lipid soluble (Clinton, 1998; Shi and Maguer, 2000; Colle et al., 2010; Colle et al., 2013; Trujillo and Mc-Clements, 2016), so that to increase lycopene absorption in the digestive tract, it must be mixed with lipid. Clark et al. (2000) found that olive oil was better than corn oil in improving lycopene absorption in the rat, because the corn oil is rich with the Polyunsaturated Fatty Acid (PUFA) like linoleic acid, while olive oil is rich with the Monounsaturated Fatty Acid (MUFA) like oleic acid. Furthermore, Clark et al. (2000) explained that lycopene is a part of carotenoid with less absorption of carotenoid in digestive tract of rat due to carotenoid oxidation which promotes by high PUFA content in corn oil and transfer of carotenoid to micelles from lipid emulsions containing large amounts of PUFA and bile salt will reduce, so that the absorption of lycopene mixed with corn oil was less than absorption of lycopene mixed with olive oil. On the other hand, Colle et al. (2012) reported the in vitro experiment about the addition of 5\% different lipid (coconut oil, palm oil, cocoa butter, olive oil, sunflower oil, and fish oil) to row tomato pulp were significantly affected the lycopene bioaccessibility. Furthermore, in the second experiment Colle et al. (2012) added of coconut oil, olive oil, and fish oil of $0,1,2,5$, and $10 \%$ to row tomato pulp, and the highest lycopene bioaccessibility for olive oil and fish oil was after adding $2 \%$ and $1 \%$ of oil respectively, while the highest lycopene bioaccessibility for coconut oil was as much as $10 \%$.

Palm oil and coconut oil are rich with saturated fatty acids like palmitic acid and lauric acid respectively (Dinicolantonio and O'Keefe, 2017). Both oils (palm oil and coconut oil) have potential to dilution of lycopene for increasing it's bioaccessibility by in vitro study (Colle et al., 2012), but the research that specifically investigates lycopene absorption by in vivo study in poultry is limited. Moreover, the digestibility of crude fiber and nitrogen retention from steaming tomato waste powder are important to evaluate, because maybe the steaming and oil addition to tomato waste will affect the content and structure of protein and crude fiber in tomatoes. According to Mahata et al. (2012), physical treatment (steaming) degraded crude fiber bond in juice waste mixture, and it also decreased crude fiber content. The addition of lipid in diet of poultry could reduce the rate of feed digestion in digestive tract, and it improved digestibility of feed nutrient (Baiao and Lara, 2005; Latshaw, 2008; Rizal, 2013). Therefore, this study was performed to evaluate the effects of coconut and palm oil addition in steaming tomato waste powder on lycopene and nitrogen retention, and crude fiber digestibility.

\section{MATERIALS AND METHODS}

\section{Ethical approval}

The animal experiments were carried out in accordance with the guidelines laid by institutional Ethics committee for the care of animals and were approved by Animal Ethics Committee of the Universitas Andalas, Padang, Indonesia with No:574/KEP/FK/2019.

\section{Coconut oil and palm oil}

Palm oil from one of the local brand (merk Rose Brand from Rose Brand inc, Jakarta, Indonesia) with the purity as much as $99.81 \%$. Coconut oil was prepared by extraction of coconut milk from a mature coconut, and then it boiled until the oil from coconut milk was produced. Furthermore, the oil was separated from coconut cake by filtration. The purity of coconut oil as much as $99.85 \%$. The fatty acid content of each coconut oil and palm oil presented in table 1.

\section{Steaming tomato powder waste}

The type of tomato used in this experiment was mature tomato (Lycopersicon esculentum) waste. It was collected from rejected tomatoes at an agricultural field in Alahan Panjang, West Sumatera province, Indonesia. The tomato waste was steamed in the boiled water at $98^{\circ} \mathrm{C}$ for 12 min (Handayani et al., 2018). Furthermore, steaming tomatoes wastes were dried in the oven at temperature $60^{\circ} \mathrm{C}$ for three days (Handayani et al., 2018) and then ground to be a powder. The nutrient content of tomato powder shown in table 2 .

Table 1. Fatty acid composition of coconut oil and palm oil

\begin{tabular}{lcc}
\hline Fatty acid & Coconut oil & Palm oil \\
\hline C4 (butyric acid) (\%) & 0 & 0 \\
C6 (caproic acid) (\%) & 0 & 0 \\
C8 (caprylic acid) (\%) & 0,23 & 0 \\
C10 (capric acid) (\%) & 4,53 & 0 \\
C12 (lauric acid) (\%) & 55,28 & 0,26 \\
C14 (myristic acid) (\%) & 21,8 & 1,26 \\
C16 (palmitic acid) (\%) & 7,34 & 35,6 \\
C18 (Stearic acid) (\%) & 3,13 & 5,07 \\
C18:1 (oleic acid) (\%) & 4,97 & 39,91 \\
C18:2 (linoleic acid) (\%) & 2,12 & 16,1 \\
\hline
\end{tabular}

Source: analysis at the Agro-Industrial Center Central Laboratory, at Bogor city, West Java, Indonesia, 2018 
Table 2. Nutrient content of tomato powder

\begin{tabular}{lc}
\hline Nutrients & Amount \\
\hline Crude protein (\%) & 10,88 \\
Crude lipid (\%) & 3,85 \\
Crude fiber (\%) & 11,92 \\
Calcium (\%) & 0,26 \\
Phosphorus (\%) & 0,69 \\
Metabolism Energy (KCal/kg) & 1596 \\
Methionine (\%) & 0,25 \\
Lysin (\%) & 0,83 \\
Lycopene (mg/100g) & 52,10 \\
\hline
\end{tabular}

\section{Experimental animals}

Totally 60 broiler chickens (strain MB 202 from Japfa comfeed inc. Indonesia) at seven weeks of age were purchased from a local broiler farm. Broiler chickens divided randomly into 10 groups combination treatment from type of oil and dosage of oil (6 bird /group) with three replicates each ( $2 \mathrm{bird} /$ replicate). Another birds as much as 6 birds were prepared for control treatment (tomato steaming powder without oil) and 4 other bird were used for collecting excreta from endogenous nitrogen. Then birds were kept in wire cages, and each cage was provided with water troughs and tray to collect excreta. The control treatment and endogenous nitrogen treatment were not statistically analysed. Endogenous nitrogen treatment was used for calculate retention nitrogen.

\section{Experimental design}

The experiment was performed in a $2 \times 5$ factorial (Steel and Torrie, 1980) arrangement of lipid addition to steaming tomato waste powder in completely randomized design (totally 10 treatments), and each treatment was replicated three times. The first factor was different type of oil (coconut oil and palm oil), and the second factor was different dosage of oil $(0.25,0.5,0.72,1$, and $1.25 \%$ in feed). The combination of treatments as follows: Addition coconut oil at different dosages as much as $0.25,0.5,0.75$, 1 , and $1.25 \%$. Also addition of palm oil at different dosages as much as $0.25,0.5,0.75,1$, and $1.25 \%$ was considered.

\section{Forced feeding}

Before forced feeding, all birds were fasted for 32 hours by modified method of Sibbald (1976) to make empty digestive tracts of the birds. The water was prepared ad libitum. $20 \mathrm{~g}$ of steamed tomato waste powder prepared in paste $(20 \mathrm{ml}$ water mixed with the tomato powder until to be paste ). Then tomato paste was added to oil as much as appropriate with each treatment $(0.25,0.5$, $0.72,1$, and $1.25 \%$ in feed), and then each bird was forced feeding. Force-feeding was accomplished by inserting a gastrointestinal tube into the esophagus. The tomato paste pushed into the crop with a syringe rod. After forcefeeding, the birds were returned to their cages. A tray was placed under each cage to collect excreta. Excreta samples from each bird was collected at 48 hours after forced feeding by modified method of Sibbald (1976). Excreta on the tray was moved to another tray every three hour and contaminants of excreta, such as feathers were removed carefully before excreta were dried. The excreta were dried in the oven at temperature $60{ }^{0} \mathrm{C}$ for 48 hours, ground to be powder for lycopene retention, nitrogen retention, and crude fiber digestibility analysis.

\section{Measurement of lycopene}

Lycopene was analyzed by modification from Sharma and Le Maguer (1996) method. $1.25 \mathrm{~g}$ of excreta powder from each bird was placed in Erlenmeyer $250 \mathrm{ml}$, covered with aluminum foil, and added with $12.5 \mathrm{ml}$ of mixed solution hexane: acetone: ethanol (2: 1: 1, v/v/v). That mixture solution was made with mixing $6.25 \mathrm{ml}$ of hexane, $3.125 \mathrm{ml}$ acetone, and $3.125 \mathrm{ml}$ of ethanol. Excreta powder that has been added with a mixed solution was shaken for 30 minutes with a magnetic stirrer, then separated by funnel separate, and $10 \mathrm{ml}$ of distilled water was added, and then shaked again for 15 minutes. At last, the the polar and non-polar layers were separated by separating funnel and all the top layer (non-polar) poured to a $25 \mathrm{ml}$ measuring flask, then added $\mathrm{N}$-hexane until mark boundaries. The total lycopene content of non-polar layer with UV-Vis spectrophotometry (UV-1800 Shimadzu Kyoto, Japan) at a wavelength of $417 \mathrm{~nm}$ was determined. Lycopene level was calculated by standard regression.

\section{Measurement of lycopene retention}

Lycopene Retention (LR) was calculated by the modification method of Jain (1999) as follows:

$\mathrm{LR}(\%)=\frac{\sum \text { lycopene consumption }-\sum \text { lycopene in excreta }}{\sum \text { lycopene consumption }} \times 100 \%$

\section{Measurement of nitrogen and crude fiber}

Nitrogen and Crude Fiber (CF) of excreta from each bird was analyzed by proximate analysis (AOAC, 1990). Measurement of nitrogen retention and CF digestibility, nitrogen retention was calculated by the method of Sibbald (1985) and CF digestibility were calculated by the method of Mujahid et al. (2003) with few modifications as follow: 
Nitrogen Retention $(\%)=\frac{\Sigma \mathrm{N} \text { consumption }-(\Sigma \mathrm{N} \text { excreta }-\Sigma \mathrm{N} \text { Endogenous })}{\Sigma \mathrm{N} \text { consumption }} \times 100 \%$

CF digestibility $(\%)=\frac{\mathrm{CF} \text { consumption }-\mathrm{CF} \text { excreta }}{\mathrm{CF} \text { consumption }} \times 100 \%$

\section{Analysis of data}

Data were statistically analyzed by one-way analysis of variance. Differences among treatments were determined with Duncan's multiple range test (DMRT) according to Steel and Torrie (1980). The significant differences was indicated at $\mathrm{P}<0.05$.

\section{RESULTS}

Lycopene retention from steaming tomato waste powder which was added with different types of oil (coconut and palm oils), and combined with different dosage of both of oils $(0.25,0.5,0.75,1$, and $1.25 \%)$ was shown in table 3 . There was interaction $(\mathrm{P}<0.05)$ between type and dosage of oil on lycopene retention. The interaction between dosage of oil at $0.25 \%$ with the type of coconut oil and palm oil showed no significant $(\mathrm{P}>0.05)$ effect on lycopene retention, as well as the interaction between dosage of oil at $0.5 \%$ with both type of oils did not significantly $(\mathrm{P}>0.05)$ affect the lycopene retention. So there were no interactions $(\mathrm{P}>0.05)$ between dosage of oil $(0.25 \%$ and $0.5 \%)$ with the type of both different oils in lycopene retention. The interaction of both palm and coconut oil dosages at $0.75,1$, and $1.25 \%$ indicated significant $(\mathrm{P}<0.05)$ effects on lycopene retention.
The result of nitrogen retention of steaming tomato waste powder with different oil types, and different dosage of oil are summarized in table 4 . It was obtained that there was no interaction $(\mathrm{P}>0.05)$ between types of oil (palm and coconut oils) and dosage of oil $(0.25,0.5,0.75,1$, and $1.25 \%$ ) on nitrogen retention, but nitrogen retention was affected by the type of oil (palm and coconut oils) significantly $(\mathrm{P}<0.05)$, and also the dosages of oil $(0.25$, $0.5,0.75,1$, and $1.25 \%)$ showed significant $(\mathrm{P}<0.05)$ effects on nitrogen retention. In this study, the dosage of oil at $0.5 \%$ was the best dosage to increase nitrogen retention compared to other oil dosages $(0.25,0.75,1$, and $1.25 \%)$.

There was significantly interactions $(\mathrm{P}<0.05)$ between the types of oil with the dosage of oil on CF digestibility (Table 5). That shows the type of oil and how much dosage of oil added affect CF digestibility in the digestive tract of broiler. CF digestibility was affected by types of oil (palm and coconut oils) significantly $(\mathrm{P}<0.05)$, and also the dosage of oil showed significant $(\mathrm{P}<0.05)$ effects on CF digestibility. The dosage of both of oils at $0.25 \%$ in diet showed the CF digestibility $(24.50 \%)$ lesser than the dietary dosage of both of oils at $0.5 \%$ (32.16\%). The highest $\mathrm{CF}$ digestibility was found in treatment coconut oil at the dosages of $0.25 \%$ and $0.5 \%$. Increasing dosages of oil $(0.75,1$ and 1.25) caused reduction in CF digestibility in both types of oil. It means that the dosages of oil should be added not more than $0.5 \%$ in other to obtain the best CF digestibility.

Table 3. Effect type and dosage of oil (coconut and palm oil) in steaming tomato waste on lycopene retention of broiler chicken

\begin{tabular}{|c|c|c|c|c|c|c|}
\hline \multirow{2}{*}{ Type of oil } & \multicolumn{5}{|c|}{ Dosage of palm oil and coconut oil (\%) } & \multirow{2}{*}{ Means } \\
\hline & 0.25 & 0.5 & 0.75 & 1 & 1.25 & \\
\hline Palm oil & $47.19^{\mathrm{bc}}$ & $57.49^{\mathrm{a}}$ & $47.16^{\mathrm{bc}}$ & $46.21^{\mathrm{bc}}$ & $41.85^{\mathrm{c}}$ & $47.98^{\mathrm{B}}$ \\
\hline Coconut oil & $49.97^{\mathrm{b}}$ & $61.74^{\mathrm{a}}$ & $57.77^{\mathrm{a}}$ & $56.46^{\mathrm{a}}$ & $58.16^{\mathrm{a}}$ & $56.82^{\mathrm{A}}$ \\
\hline Means & $48.58^{\mathrm{b}}$ & $59.62^{\mathrm{a}}$ & $52.46^{\mathrm{b}}$ & $51.34^{\mathrm{b}}$ & $50.00^{\mathrm{b}}$ & \\
\hline
\end{tabular}

${ }^{\mathrm{a}-\mathrm{c} M e a n s}$ values in the same row bearing different superscripts are significantly different $(\mathrm{P}<0.05),{ }^{\mathrm{A}-\mathrm{B}}$ Means values in the same column bearing different superscripts are significantly different $(\mathrm{P}<0.05), \mathrm{SEM}=1,71$ 
Table 4. Effect type and dosage of oil (coconut and palm oil) in steaming tomato waste on on nitrogen retention of broiler chicken

\begin{tabular}{|c|c|c|c|c|c|c|}
\hline \multirow{2}{*}{ Type of oil } & \multicolumn{5}{|c|}{ Dosage of Dosage of palm oil and coconut oil (\%) } & \multirow{2}{*}{ Means } \\
\hline & 0.25 & 0.5 & 0.75 & 1 & 1.25 & \\
\hline Palm oil & 34.67 & 46.16 & 35.01 & 26.79 & 22.38 & $33.00^{\mathrm{B}}$ \\
\hline Coconut oil & 54.43 & 62.39 & 47.69 & 46.79 & 38.93 & $50.05^{\mathrm{A}}$ \\
\hline Means & $44.55^{\mathrm{b}}$ & $54.28^{\mathrm{a}}$ & $41.35^{\mathrm{b}}$ & $36.79^{\mathrm{c}}$ & $30.65^{\mathrm{d}}$ & \\
\hline
\end{tabular}

Table 5. Type and dosage of oil (coconut and palm oil) in steaming tomato waste on on crude fiber digestibility of broiler chickens

\begin{tabular}{|c|c|c|c|c|c|c|}
\hline \multirow{2}{*}{ Type of oil } & \multicolumn{5}{|c|}{ Dosage of Dosage of palm oil and coconut oil (\%) } & \multirow{2}{*}{ Means } \\
\hline & 0.25 & 0.5 & 0.75 & 1 & 1.25 & \\
\hline Palm oil & $15.65^{\mathrm{c}}$ & $28.05^{\mathrm{b}}$ & $11.60^{\text {cde }}$ & $11.35^{\mathrm{de}}$ & $9.29^{\mathrm{e}}$ & $15.19^{\mathrm{B}}$ \\
\hline Coconut oil & $33.36^{\mathrm{a}}$ & $36.26^{\mathrm{a}}$ & $15.34^{\mathrm{cd}}$ & $14.82^{\mathrm{cd}}$ & $13.03^{\text {cde }}$ & $22.56^{\mathrm{A}}$ \\
\hline Means & $24.50^{\mathrm{b}}$ & $32.16^{\mathrm{a}}$ & $13.47^{\mathrm{c}}$ & $13.09^{\mathrm{c}}$ & $11.16^{\mathrm{c}}$ & \\
\hline
\end{tabular}

${ }^{\mathrm{a}-\mathrm{e}}$ Means values in the same row bearing different superscripts are significantly different $(\mathrm{P}<0.05),{ }^{\mathrm{A}-\mathrm{B}}$ Means values in the same column bearing different superscripts are significantly different $(\mathrm{P}<0.05), \mathrm{SEM}=1,24$

\section{DISCUSSION}

Based on the result in this experiment, there was interaction between type and dosage of oil on lycopene retention. The lycopene retention at the dosage of $0.25 \%$ and $0.5 \%$ for both types of oils was not different. While, lycopene retention in tomato waste powder of steaming tomato with coconut oil at dosages of $0.75,1$, and $1.25 \%$ was as much as waste powder of steaming tomato with coconut oil at dosages of $0.5 \%$. Lycopene retention in waste powder of steaming tomato with palm oil at dosages of $0.75,1$, and $1.25 \%$ decreased lycopene retention in comparing with $0.5 \%$ dosage. This condition showed when the dosage of oil is low (less than $0.5 \%$ ), fatty acid from coconut oil and palm oil (Table 1) are able to solve the lycopene in micelle (an aggregate of molecules in a collodial solution) of poultry digestive tract. Therefore lycopene absorption can be easily in digestive tract. When the oil dosage is high (more than $0.5 \%$ ) in waste powder of steaming tomato, the medium chain saturated fatty acid in coconut oil appear better than palm oil which contains long chain saturated fatty acid to solve lycopene in micelle. According to Li et al. (2011) when in digestive tract the lipid load is high, triglycerides with long chain fatty acids will hydrolysis by enzyme (lipase), although this hydrolysation was lesser for triglycerides with medium chain fatty acids. Acording to Agarwal and Rao (1998) Lycopene is a part of carotenoid. An experiment on simulation of gastric-duodenal fluid that showed the dilution of carotenoid in oil which not combined with micelles is higher than carotenoid in oil which combained with micelle (Malaki et al., 2010). That is the reason why the lycopene from steaming tomato waste powder which added with palm oil which contains long-chain fatty acid less absorption when high lipid load in digestive tract in this experiment. According to Huo et al. (2007) the addition of $0.25,0.5,1,2.5 \%$ of coconut oil to salads which consist of $20 \%$ spinach, 35\% tomatoes, $25 \%$ carrots, $10 \%$ lettuce, $10 \%$ yellow peppers, compared to salad which obtained $0.25 \%$ to $1 \%$ of coconut oil did not affect the micellarization of lycopene, but the micellarization increased after adding of coconut oil at dosage $2.5 \%$. Colle et al. (2012) in an in vitro experiment, reported that lycopene bioaccessibility increased after addition of $0,1,2,5$, to $10 \%$ coconut oil. Moreover, Colle et al. (2012) expressed the addition of $2 \%$ olive oil with high long-chain fatty acid to tomato pulp, caused the highest lycopene bioaccessibility but this bioaccessibility was decreased in higher levels of olive oil. Beside that, this experiment discribes that lycopene retention in tomato waste by emulsification with coconut oil better than emulsification with palm oil. Because coconut oil contain less unsaturated fatty acids than palm oil (table 1). The oils with high unsaturated fatty acid highly susceptible to oxidation, forming highly reactive radicals, resulting lycopene depletion. Because lycopene prevent unsaturated fatty acids from being oxidised and resulting in less 
absorption of available lycopene in intestinal tarct (Clark et al., 2000).

Lycopene retention in this study was obtained $40.19 \%$ (data not displayed) at the control treatment (no oil addition), and $41.85 \%$ to $61.74 \%$ for the treatment combination the type and dosage of oil in steaming tomato waste powder. Lycopene retention in this study showed a good influence to increase the absorption of lycopene in poultry digestive tract, because of both types of oil (palm and coconut oils) were supporting factor for lycopene absorption in poultry digestive tract. The increasing of lycopene absorption in the digestive tract of poultry due to lycopene is a part of carotenoid. These carotenoid compounds are soluble in oil (Reboul, 2019). Both of oils and lycopene in the digestive tract of poultry would be absorbed in the micelles form. Micelles consist of carotenoid compounds, monoglycerides, and free fatty acids produced by hydrolysis of lipids in digestive tract (Yonekura and Nagoa, 2007). Monoglycerides, and free fatty acids produced by hydrolysis of oil would increase the formation of micelles, consequently lycopene will be more entered into the micelle and absorbed by the body through enterocytes. So that presence lipid would increase lycopene absorption (Hof et al., 2000; Yonekura and Nagao, 2007; Colle et al., 2012; Trujillo and McClements, 2016).

Carotenoid absorption such as $\beta$-carotene was reported by Williams et al. (1998) ranged from 2 to $50 \%$. The absorption is possible from food ingredients and independently from outside of foods. Jain (1999) stated that from $143 \mu \mathrm{g}$ of lycopene given daily to mice, just $105 \mu \mathrm{g}$ (73\%) could absorb. According to Hof et al. (2000) and Trujillo and Mc-Clements (2016) absorption in foods containing carotenoids can be improved by processing. The heat processing will disrupt cell wall structure in plant thus can be released charotenoids from chromoplasts and increase their bioaccessibility (Trujillo and Mc-Clements, 2016) as well as it can change trans form to cis form (Basaran et al., 2017). In present study, lycopene retention have high value compared to previous studies, which was because of tomato waste powder that was a product from steam processing. Steaming of tomato wastes for 12 minutes at $98^{\circ} \mathrm{C}$ supported releasing of lycopene from tomato matrix and undergo isomerization of lycopene from trans form to cis form. The release of lycopene from tomato matrix will increase the availability of lycopene, while the cis form of lycopene will be absorbed more easily than to trans lycopene form. According to Boileau et al. (1999) and Knockaert et al. (2012), the cis isomer of lycopene was more easily absorbed than the trans lycopene isomer in the digestive tract.

Nitrogen retention and CF digestibility of steaming tomato waste powder increased after adding both of palm and coconut oils compared with nitrogen retention and $\mathrm{CF}$ digestibility at tomato waste powder without oil addition (data not displayed). It means, the addition of both type of oils to waste powder of steaming tomato affected the digestion rate in the digestive tract of poultry. The reason can be related to the actions of protease enzyme for hydrolyze protein and lipase enzyme to hydrolize lipid from waste powder of steaming tomato in intestinal lumen of animals. The addition fat to animal feed reduced the passage rate of the digesta in the gastrointestinal tract, and allowed better absorption of all nutrients presented in the feed (Baiao and Lara, 2005; Latshaw, 2008; Rizal, 2013). The addition of $0.25 \%$ of oil to steaming tomato waste powder resulted in nitrogen retention $44.55 \%$, and increased to $54.28 \%$ when dosage of oil increased to $0.5 \%$, however in the dosage of oil at $0.75,1$, and $1.25 \%$, nitrogen retention decreased to $41.28 \%, 36.79 \%$ and $30.65 \%$ respectively. The decreasing of nitrogen retention caused by addition of higher dosages of oil (more than $0.5 \%$ ), can be explained by accumulation of lipids in gastrointestinal, which causes low hydrolyze of triglycerides contained in the oil via lipase enzymes, and it mixed with CF contained in the steaming tomatoes waste, so triglycerides would be taken out of the digestive tract and nitrogen retention will be reduced.

The CF content in tomato waste powder was high (12\%), which increase the viscosity of the digestive tract, and accelerate the rate of feed in the digestive tract. Therefore the digestibility of $\mathrm{CF}$ decreased when the dosage of both oils (palm and coconut oils) increased from $0.5 \%$ to $0.75,1$, and $1.25 \%$. Paudel (2013) reported the effect of different types of oil like soybean oil (4\%), and the combination of $2 \%$ rapeseed oil with $2 \%$ flaxseed oil on fat digestibility in broiler chickens and reported that the volume and viscosity of feed in the small intestine increased and the excreta from jejunum had much more liquid and so this might be a reason of low digestion. The range of CF digestibility in present study was from 9.29\% to $36.26 \%$. This finding was lower than the report of Mahata et al. (2018) that indicated CF digestibility of unboiled and boiled tomatoes added to broiler diet was from $37.61 \%$ to $51.28 \%$ respectively.

\section{CONCLUSION}


The addition of coconut oil in steaming tomato waste powder increased lycopene and nitrogen retention, and crude fiber digestibility higher than the addition of palm oil to steaming tomato waste powder in the broiler. The best level for lycopene and nitrogen retention, and crude fiber digestibility in broiler was for group that added $0.5 \%$ coconut oil to the diet.

\section{DECLARATIONS}

\section{Acknowledgments}

This Research was funded by the Ministry of Research Technology and Higher Education of the Republic of Indonesia through PMDSU programe. We are very Grateful to Ministry of Research Technology, and Higher Education of the Republic of Indonesia and Rector of Universitas ANDALAS for their support in this program. We are very grateful to the Minister of Research, Technology and Higher Education of the Republic of Indonesia for support and finance through PMDSU No: 1387 / E4. 2015 and Rector of Universitas ANDALAS for their support in this program.

\section{Competing interests}

The authors declare that they have no competing interests.

\section{Author's contribution}

Handayani were involved in the data collecting, statistical analysis and drafting of the manuscript. Wizna, Suliansyah, Rizal, and Mahata read and approved the final manuscript.

\section{Consent to publish}

All authors gave their informed consent prior to their inclusion in the study.

\section{REFERENCES}

Agarwal S and Rao AV (1998). Tomato Lycopene and Low Density Lipoprotein Oxidation: A Human Dietary Intervention Study. Lipid, 33: 981-984.

AOAC (1990). Association of Official Analytical Chemists. Official Method of Analysis, 15th edition. Washington DC. pp 69-88.

Baiao NC and Lara LJC (2005). Oil and Fat in Broiler Nutrition. Brazilian Journal of Poultry Science, 7: 129-141.

Basaran N, Bacanli M and Basaran AA (2017). Chapter 28: Lycopenes as Antioxidants in Gastrointestinal Diseases. Antioxidants and Gastroenterology. Section II, Gastrointestinal Tissue: 355-362. Available at:https://10.1016/B978-0-12-805377-5.00028-X
Boileau AC, Merchen NR, Wasson K, Atkinson CA and Erdman JW (1999). Cis-lycopene is More Bioavailable than Trans-lycopene in-Vitro and in-Vivo in LymphCannulated Ferrests. Journal Nutritional Sciences, 129: 1176-1181.

Bramley PM (2000). Is lycopene beneficial to human health? Phytochemistry, 54: 233-236.

Clark RM, Yao L, She L and Furr HCA (2000). Comparison of Lycopene and Astaxanthin Absorption from Corn Oil and Olive Oil Emulsion. Lipid, 35(7): 1-5. DOI:http://doi.org/10.1007/s11745-000-0589-8

Clinton SK (1998). Lycopene: Chemistry, Biology, and Implications for Human Health and Disease. Nutrition Review, 56 (2): 35-51.

Colle IJP, Buggenhout SV, Lemmens L, Loey AMV and Hendrickx ME (2012). The Type and Quantity of Lipids Present During Digestion Influence the In-Vitro Bioaccessibility of Lycopene from Raw Tomato Pulp. Food Research International, 45: 250-255. DOI:http://doi.org/10.1016/j.foodres.2011.10.041

Colle IJP, Lemmens L, Buggenhout SV, Loey AMV and Hendrickx ME (2010). Effect of Thermal Processing on the Degradation, Isomerization, and Bioaccessibility of Lycopene in Tomato Pulp. Journal of Food Science, 75: 753-759. 3841.2010.01862.x

Colle IJP, Lemmens L, Buggenhout SV, Met K, Loey AMV and Hendrickx ME (2013). Processing Tomato Pulp in The Presence of Lipids: The Impact on Lycopene Bioaccessibility. Food Research International, 51: 32-38. DOI:http://dx.doi.org/10.1016/j.foodres.2012.11.024

Dewanto V, Xianzhong W, Adom KK and Liu RH (2002). Thermal Processing Enhances the Nutritional Value of Tomatoes by Increasing Total Antioxidant Activity. Journal of Agricultural and Food Chemistry, 50: 30103014. DOI:http://doi.org/10.1021/jf0115589

Dinicolantonio JJ and O'Keefe JH (2017). Good Fats versus Bad Fats: A Comparison of Fatty Acids in the Promotion of Insulin Resistance, Inflammation, and Obesity. Science of Medicine, 114 (4): 303-307.

Gupta A, Kawatra A and Sehgal S (2011). Physical-chemical Properties and Nutritional Evaluation of Newly Developed Tomato Genotypes. African Journal of Food Science and Technology, 2(7): 167-172. Available at:http://www.interesjournals.org/AJFST; Internet; accessed 30 April 2019.

Handayani UF, Suliansyah I, Rizal Y and Mahata ME (2018). Effect of Heating Method on Lycopene, Dry Matter and Nutrient Content of Tomato (Lycopersicon esculentum) Waste as Laying Hen Feed. Internationan Journal of Poultry Science. 17, 63-70. DOI: 10.3923/ijps.2018.63.70

Hof KHV, West CE, Weststrate JA and Hautvast JGAJ (2000). Dietary Factors That Affect the Bioavailability of Carotenoids. Recent Advances in Nutritional Sciences, 503-506. Available at:https://academic.oup.com/jn/articleabstract/130/3/503/4686253; Internet; accessed 30 April 2019.

Huo T, Ferruzzi MG, Schwartz SJ and Failla ML (2007). Impact of Fatty Acyl Composition and Quantity of 
Triglycerides on Bloaccessibility of Dietary Carotenoids. Journal of Agricultural and Food Chemistry, 55(22): 89508957. DOI:http://doi.org/10.1021/jf071687a

Jain CK (1999). Studies on the Bioavailablity, Tissue Distribution, Antioxidant and Anticarcinogenic Properties of Dietary Lycopene in Rats. Thesis for the degree of Master of Science Graduate Department of Nutritional Sciences University. pp. 39-48. Available at:http://wwwcollectionscanada.ca/obj/s4/f2/dsk1/tape9/PQ DD_0002/MQ46129.pdf\&ved=2ahUKEwjfzavTp_LkAhU Cgl8KHf0EDm4QFjANegQ1AhAB\&usg=; Internet; accessed 30 April 2019.

Knockaert G, Pulissery SK, Colle I, Buggenhout SV, Hendrickx M and Loey AV (2012). Lycopene Degradation, Isomerization and in Vitro Bioaccessibility in High Pressure Homogenized Tomato Puree Containing Oil: Effect of Additional Thermal and High Pressure Processing. Food Chemistry, 135: 1290-1297. DOI: 10.1016/j.foodchem.2012.05.065

Latshaw JD (2008). Daily Energy Intake of Broiler Chickens is Altered by Proximate Nutrient Content and Form of The Diet. Poultry 8cience, 87:89-95. DOI:http://doi.org/10.3382/ps.2007-00173

Li Y, Hu M and Mcclements DJ (2011). Factors Affecting Lipase Digestibility of Emulsified Lipids Using an in Vitro Digestion Model: Proposal for a Standardised $\mathrm{pH}$-stat method. Food Chemistry, 126(2): 498-505. DOI:http://dx.doi.org/10.1016/j.foodchem.2010.11.027

Mahata ME, Rizal Y and dan Ardi (2018). Tomat (Licopersicon esculentum) Limbah sebagai Bahan Pakan Ternak Unggas [Tomato (Licopersicon esculentum) waste as Poultry Feed]. Sukabina Press, Padang. Indonesia. pp. 1-135.

Mahata ME, Rizal Y and Wu G (2012). Improving the Nutrien Quality of Juice Waste Mixture by Steam Pressure for Poultry Diet. Pakistan Journal Nutrition, 11: 172-175.

Mahata ME, Manik J, Taufik M, Rizal Y and Ardi (2016a). Effect of Different Combinations of Unboiled and Boiled Tomato Waste in Diet on Performance, Internal Organ Development and Serum Lipid Profile of Broiler Chicken. International Journal Poultry Science, 15: 283-286.

Mahata ME, Rizal Y, Hermansyah D and Nurhuda GA (2016b). Effects of Boiled Tomato Waste Utilization in the Diet on Serum Lipid Profile and Egg Quality of Laying-hens. International Journal Poultry Science, 15: 493-496. DOI:http://10.3923/ijps.2016.493.496

Malaki NA, Corredig M and Wright AJ (2010). Changes in WPIStabilized Emulsion Interfacial Properties in Relation to Lipolysis and $\beta$-carotene Transfer during Exposure to Simulated Gastric-Duodenal Fluids of Variable Composition. Food Digestion, 1(1): 14-27. DOI:http://dx.doi.org/10.1007/s13228-010-0002-1

Mangiagalli MG and Taylor P (2010). Effect of Lycopene on Semen Quality, Fertility and Native Immunity of Broiler Breeder. British Poultry Science, 51: 152-157 DOI:http://dx.doi.org/10.1080/00071660903401540

Meroni, E and Raikos V (2018). Lycopene in Beverage Emulsions: Optimizing Formulation Design and Processing Effects for Enhanced Delivery. Review. Beverages Journal,
4

(14):

$1-10$.

DOI:http://dx.doi.org/10.3390/beverages4010014

Mujahid A, Asif M, Haq I, Abdullah M and Gilani AH (2003). Nutrient Digestibility of Broiler Feeds Containing Different Levels of Variously Processed Rice Bran Stored for Different Periods. Poultry Science, 82:1438-1443. Available at:https://academic.oup.com/ps/article-

abstract/82/9/1438/1537615; Internet; accessed 30 April 2019.

Olson JB, Ward NE and Koutsos EA (2005). Lycopene Incorporation into Egg Yolk and Effects on Laying Hen Immune Function. Poultry Science, 87: 2573-2580 DOI:http://doi.org/10.3382/ps.2008-00072

Palozza P, Catalano A, Simone RE, Mele MC and Cittadini A (2012). Effect of Lycopene and Tomato Products on Cholesterol Metabolism. Annal Nutrition and Metabolism, 61:126-134. DOI:http://doi.org/10.1159/000342077

Paudel S (2013). Two Different Oils in Feeds for Broiler: Effect on Fat Digestion. Master of Thesis. Departement of Animal Science and Aquacultural Sciences, Norwegian University of life science. Pp. 1-26. Available at: Available at:http://nmbu.brage.unit.no/nmbuxmlui/bitstream/handle/11250/186189/paudel_master2013.p df\%3Fsequence\%3D4\%26isAllowed\%3Dy\&ved=

Reboul E (2019). Mechanisms of Carotenoid Intestinal Absorption: Where Do We Stand? Nutrients, 11 (838): 112. DOI:http://doi.org/10.3390/nu11040838

Rizal Y (2013). Ilmu Nutrisi Unggas (Poultry Nutrition). Andalas University Press; Padang, Indonesia. pp. 34-66.

Sharma SK and Le Maguer M (1996). Lycopene in Tomato Pulp Fractions. Italian Journal of Food Science, 8: 107113.

Shi J and Le Maguer M (2000). Lycopene in Tomatoes: Chemical and Physical Properties Affected by Food Processing. Critical Reviews in Food Science and Nutrition, DOI:http://doi.org/1080/10408690091189275

Sibbald IR (1976). A Bioassay for True Metabolizable Energy in Feedingstuffs. Poultry Science, 1: 303-308.

Sibbald IR (1985). Relationships Between Estimates of Bioavailable Energy Made with Adult Cockerels and Chicks: Effects of Feed Intake and Nitrogen Retention. Poultry Science, 64: 127-138.

Steel RGD and Torrie JH (1980). Principles and Procedures of Statistics: A Biometrical Approach. 2nd edition. New York, USA: (McGraw-Hill, Inc). pp. 187-188 and 336-376.

Sun B, Chen C, Wang W, Ma J, Xie Q, Gao Y, Chen F, Zhang X and Bi Y (2015). Effects of Lycopene Supplementation in Both Maternal and off Spring Diets on Growth Performance, Antioxidant Capacity and Biochemical Parameters in Chicks. Journal of Animal Physiology and Animal Nutrition, (99): 42-49. DOI:http://10.1111/jpn.12196

Surai PF (2016). Antioxidant Systems in Poultry Biology: Superoxide Dismutase. Review Article. Animal Nutrition, 1(1):8: 1-17. 
Toor RK and Savage GP (2005). Antioxidant Activity in Different Fractions of Tomatoes. Food Research International, 38: 487-494. DOI:http://doi.org/10.1016/j.foodres.2004.10.016

Trujillo L S and Mc-Clements DJ (2016). Enhancement of Lycopene Bioaccessibility From Tomato Juice Using Excipient Emulsions: Influence of Lipid Droplet Size. Food Chemistry, 210: 295-304. DOI:http://10.1016/j.foodchem.2016.04.125

Unlu NZ, Bohn T, Francis DM, Nagaraja HN, Clinton SK, and Schwartz SJ (2007). Lycopene from Heat-Induced cisisomer-rich Tomato Sauce is More Bioavailable than from all-trans-rich Tomato Sauce in Human Subjects. British Journal of Nutrition, 98(1):140-146. DOI:http://10.1017/S0007114507685201

Williams AW, Bioleau TWM and Erdman JW (1998). Factors Influencing the Uptake and Absorption of Carotenoid. Experimental Biologi Medicine, 218 (2): 106-108. DOI:http://doi.org/10.3181/00379727-218-44275

Yonekura L and Nagao A (2007). Intestinal Absorption of Dietary Carotenoids. Molecular Nutrition and Food Research, 51(1): 107-115. DOI:http://doi.org/10.1002/mnfr.200600145 